\title{
Копытовский Д.С. \\ Роль актов Европейского суда по правам человека в международно-правовой ответственности
}

Кубанский государственный аграрный университет им. И. Т. Трубилина

(Россия, Краснодар)

doi: 10.18411/trnio-12-2021-175

\section{Аннотация}

В статье рассматривается проблема роли актов Европейского Суда по правам человека, как важнейшего рычага в деле восстановления государствами нарушенных прав, реализации принципа юридической ответственности государств-членов Совета Европы за нарушение прав и свобод человека. Действительно, роль актов Европейского суда по правам человека в международно-правовой ответственности высока в современном мире, но выделены проблемные зоны использования постановлений Европейского суда по правам человека на международной арене и в современной России. Анализ мировой науки и практики также показывает повышенное внимание к проблеме ответственности органов государственной власти перед обществом. Вне всяких сомнений, такая тема актуальна в настоящее время.

Ключевые слова: Европейский суд по правам человека, международное право, государственная власть, ответственность, международное сообщество.

\section{Abstract}

The article examines the problem of the role of acts of the European Court of Human Rights, as the most important lever in the restoration of violated rights by states, the implementation of the principle of legal responsibility of the member states of the Council of Europe for violation of human rights and freedoms. Indeed, the role of the acts of the European Court of Human Rights in international legal responsibility is high in the modern world, but problem areas of the use of judgments of the European Court of Human Rights in the international arena and in modern Russia are highlighted. The analysis of world science and practice also shows increased attention to the problem of the responsibility of public authorities before society. Without a doubt, this topic is relevant at the present time.

Keywords: European Court of Human Rights, international law, state power, responsibility, international community.

Принятие важных пактов и конвенций по правам человека международными организациями, их ратификация национальными парламентами, признание государствами международных стандартов в области прав человека и их закрепление в национальном законодательстве не только ставят вопросы об осуществлении и защите этих прав на повестку дня, но также и о ответственности государств за их нарушения [1, с.8]. Анализ мировой науки и практики также показывает повышенное внимание к проблеме ответственности органов государственной власти перед обществом.

Правовая ответственность государства проявляется, прежде всего, в закреплении в законодательстве права на возмещение в суде материального и морального вреда, причиненного незаконными действиями или бездействием государственных органов и их должностных лиц [2, с.65].

Вопросы компенсации ущерба, причиненного в результате нарушения права каждого на справедливое судебное разбирательство, решаются на международном уровне в Конвенции о защите прав человека и основных свобод, которая является неотъемлемой частью правовой системы государств, которые присоединились к Конвенции (всего 47 европейских государств, включая РФ 
Важным шагом в деле реализации принципа ответственности государств за нарушение прав и свобод человека и гражданина (негативной стороны ответственности) стало реформирование международных институтов защиты прав человека, созданных на основании Европейской конвенции о защите прав человека и основных свобод. С 1 ноября 1998 года, после вступления в силу Протокола № 11, два института, занимавшиеся защитой прав и свобод человека (Европейская комиссия по правам человека, Европейский Суд по правам человека) были заменены единым, постоянно действующим Европейским Судом по правам человека с местом расположения в Страсбурге (Франция).

Реорганизация положительно сказалась на деятельности данной международной инстанции. Об этом свидетельствует рост числа принятых решений по вопросам нарушения государствами Конвенции о защите прав человека и основных свобод. Так, если с 1959 года (момента создания Европейского Суда) и до конца 1998 года (когда он был реформирован), то есть за 40 лет он принял решения по существу в 837 делах (в среднем 21 дело в год). После реформы Суда в 1998 году и до начала 2010 года (всего за 11 лет) суд вынес уже 12 198 решений по существу (в среднем 1108,9 решений в год), из них в 10156 констатировал нарушения конвенции или её протоколов [7]. Пик обращений и жалоб в Европейский суд пришелся на 2011 год, когда очередь из жалоб составила более 151 тыс. После этого произошел отток, и в 2016 году очередь была на уровне порядка 80 тыс. жалоб. Согласно отчету ЕСПЧ за 2016 год, всего суд вынес 993 решения в отношении всех стран, признавших юрисдикцию Европейского суда. 24 января 2019 г. Европейский Суд опубликовал отчет за 2018 г., согласно данным которого на рассмотрении ЕСПЧ находится 56 тыс. жалоб [3, с. 24].

Рост числа дел, поступающих в Европейский суд, вынуждает Совет Европы постоянно принимать меры, направленные на повышение эффективности его деятельности. Результатом работы по реформированию Европейского суда стал вступивший в силу в 2010 году Протокол № 14 к Европейской конвенции о защите прав и основных свобод, призванный упростить и ускорить систему рассмотрения дел.

Протокол № 15 и протокол № 16 Европейской конвенции о защите прав человека и основных свобод, открытый для подписания сыграли важную роль в повышении эффективности работы Европейского суда.

Юрисдикция Европейского Суда по правам человека и без специального соглашения обязательна по вопросам толкования и применения Конвенции и Протоколов к ней.

Россияне активно используют этот канал защиты и восстановления своих прав. Из Отчета Европейского Суда за 2018 г. следует, что Россия заняла лидирующее место по числу рассматриваемых жалоб на нарушения Конвенции о защите прав человека и основных свобод (11,7 тыс. жалоб из 56 тыс.), что составляет 20,9\% от их общего количества. Этот всплеск свидетельствует о доверии россиян к европейскому механизму защиты прав человека, а также о том значении, которое они ему придают.

Как следует из документа, в 2018 году Страсбургский суд вынес 248 постановлений в отношении Российской Федерации, и только в пяти делах нарушений Конвенции не было. Увеличение количества жалоб от россиян также было продиктовано массовыми арестами на несанкционированных митингах [4, с.120].

Европейский суд не является высшим органом судебной системы государстваучастника Конвенции. Следовательно, он не может отменить решение государственного органа или национального суда. Однако суд имеет право присудить "справедливую компенсацию" в виде денежной компенсации материального и морального вреда, а также компенсацию выигравшей стороне всех издержек. Невыполнение решений Суда государствами-членами Совета Европы может привести к приостановлению членства этого государства и, в конечном итоге, исключением государства из состава Совета Европы». Нужно отметить, что Европейский суд принимает иски непосредственно к государству и деньги взыскиваются со счетов государства [5, с.41] (из бюджетов государства).

Средний срок исполнения Россией постановлений ЕСПЧ составил 9,7 года, что превышает сроки исполнения постановлений ЕСПЧ в других странах Совета Европы [6, 
c.23]. Три четверти постановлений ЕСПЧ просто не выполняются российскими властями. Россия также оказалась единственной страной Совета Европы, где законодательно (с 2015 года) власти установили право властей полностью или частично игнорировать решения Европейского суда по правам человека. По состоянию на сентябрь 2018 года из 2380 постановлений ЕСПЧ против России российские власти исполнили только 608 постановлений.

Таким образом, дела в Суде Европейских сообществ способствуют выявлению пробелов в национальном законодательстве и правоприменительной практике. Принимая решение о нарушении прав человека государством, Европейский суд обращает внимание властей на наиболее уязвимые положения нормативных правовых актов и нарушения в правоприменительной практике, указывает на необходимость согласования национального законодательства и процедур применения закона с нормами Европейской конвенции о правах человека. Проблема реальной ответственности государства за нарушение прав человека не может быть решена без совершенствования национального законодательства.

$$
* * *
$$

1. Карасёва Л.В. Значение норм международного частного права в регулировании трудовых отношений мигрантов из стран снг в российской федерации. автореферат диссертации на соискание ученой степени кандидата юридических наук / Российский государственный социальный институт. Москва, 2007. С. 8

2. Саенко Д.Г., Кудрявцева Л.В. Защита и осуществление прав граждан российской федерации за рубежом // Полиматис. 2017. № 3. С. 65.

3. Романова, В. В. Юридическая ответственность государства /В. В. Романова. - Текст: непосредственный // Юридическая наука и правоохранительная практика. - 2016. - № 3 (37). - С. 23-29.

4. Алисиевич, Е. С. Реформа Европейского Суда по правам человека: новые пути решения старых проблем / Е. С. Алисиевич. - Текст: непосредственный. // Вопросы цивилистической науки и современность. Вестн. Волгогр. гос. ун-та. Сер. 5. Юриспруд. - 2011. - N 1 (14) - С.118-124.

5. Кудрявцева Л.В. Значение норм международного частного права в регулировании трудовых отношений мигрантов из стран снг в российской федерации. Лариса Кудрявцева; М-во образования и науки РФ, Российский гос. социальный ун-т, фил. в г. Анапе. Краснодар, 2011. С. 41.

6. Филатова, В. В. Реформа Европейского Суда по правам человека: проблемы и перспективы /В. В. Филатова. Текст: непосредственный // Международное право. Европейское право. Журнал Вопросы экономики и права. - 2015. - № 3. - С. 23-25.

\section{Копытовский Д.С. \\ Участие адвоката в гражданско-процессуальных делах}

Кубанский государственный аграрный университет им. И. Т. Трубилина (Россия, Краснодар)

doi: 10.18411/trnio-12-2021-176

\section{Аннотация}

В данной научной работе автор раскрыл основные положения участия адвоката в гражданско-процессуальных делах. Отмечено, что юридическая помощь и судебная помощь не тождественны. Юридическая помощь оказывается по запросу клиента, в случае судебной помощи адвокат назначается коллегией адвокатов по запросу судебного органа. Приведены базовые юридические знания адвоката, несколько общих областей науки. Делается небольшой анализ роли адвоката в гражданском судопроизводстве. Вне всяких сомнений, такая тема актуальна в настоящее время.

Ключевые слова: гражданское судопроизводство, право, адвокат, юрист, суд, процесс, иск, стадии дела.

\section{Abstract}

In this scientific work, the author revealed the main provisions of the participation of a lawyer in civil procedural cases. It is noted that aid and judicial aid are not identical. Legal assistance is provided at the request of the client; in the case of judicial assistance, a lawyer is 